\title{
Leucine-rich repeat-containing G-protein-coupled receptor 8 in mature glomeruli of developing and adult rat kidney and inhibition by insulin-like peptide-3 of glomerular cell proliferation
}

\author{
P Fu ${ }^{1}$, P-J Shen ${ }^{1}$, C-X Zhao ${ }^{1}$, D J Scott ${ }^{1,2}$, C S Samuel ${ }^{1,2}$, \\ J D Wade ${ }^{1,2}$, G W Tregear $^{1,2}$, R A D Bathgate ${ }^{1,2}$ \\ and A L Gundlach ${ }^{\mathbf{1}, 3}$ \\ ${ }^{1}$ Howard Florey Institute, ${ }^{2}$ Department of Biochemistry and Molecular Biology, ${ }^{3}$ Department of Anatomy and Cell Biology, The University of Melbourne, \\ Victoria 3010, Australia \\ (Requests for offprints should be addressed to A L Gundlach; Email: a.gundlach@hfi.unimelb.edu.au) \\ (P Fu is now at Department of Medicine, Monash University, Alfred Hospital, Prahran, Victoria 3181, Australia)
}

\begin{abstract}
Leucine-rich repeat-containing G-protein-coupled receptor 8 (LGR8, or RXFP2) is a member of the type C leucine-rich repeat-containing $G$ protein-coupled receptor family, and its endogenous ligand is insulin-like peptide-3 (INSL3). Although LGR8 expression has been demonstrated in various human tissues, including testis, ovary, brain and kidney, the precise roles of this receptor in many of these tissues are unknown. In an effort to better understand INSL3-LGR8 systems in the rat, we cloned the full-length $\operatorname{Lgr} 8 \mathrm{cDNA}$ and investigated the presence and cellular localization of $\operatorname{Lgr} 8 \mathrm{mRNA}$ expression in adult and developing rat kidney. On the basis of these findings, we investigated the presence and distribution of renal ${ }^{125}$ I-labelled human INSL3-binding sites and the nature of INSL3-LGR8 signalling in cultured renal cells. Thus, using in situ hybridization histochemistry, cells expressing Lgr8 mRNA were observed in glomeruli of renal cortex from adult rats and were tentatively identified as mesangial cells. Quantitative,
\end{abstract}

real-time PCR analysis of the developmental profile of Lgr8 mRNA expression in kidney revealed highest relative levels at late stage gestation (embryonic day 18), with a sharp decrease after birth and lowest levels in the adult. During development, silver grains associated with $\operatorname{Lgr} 8$ mRNA hybridization were observed overlying putative mesangial cells in mature glomeruli, with little or no signal associated with less-mature glomeruli. In adult and developing kidney, specific ${ }^{125}$ I-INSL3-binding sites were associated with glomeruli throughout the renal cortex. In primary cultures of glomerular cells, synthetic human INSL3 specifically and dose-dependently inhibited cell proliferation over a $48 \mathrm{~h}$ period, further suggesting the presence of functional LGR8 (receptors) on these cells (mesangial and others). These findings suggest INSL3LGR8 signalling may be involved in the genesis and/or developmental maturation of renal glomeruli and possibly in regulating mesangial cell density in adult rat kidney.

Journal of Endocrinology (2006) 189, 397-408

\section{Introduction}

Insulin-like peptide-3 (INSL3), also known as relaxin-like factor, belongs to the insulin/relaxin superfamily that now comprises at least ten members in mammals (Ivell 1997, Bathgate et al. 2003, Hsu 2003). INSL3 is a developmentally regulated hormone with sexually dimorphic expression (Balvers et al. 1998, Zimmermann et al. 1999). In male rats, Insl3 expression is high before birth at day 19 of gestation in Leydig cells of fetal testes and declines after birth (Boockfor et al. 2001). Insl3 mRNA levels remain low in mesenchymal Leydig cell precursors until sexual maturation and initiation of spermatogenesis (Spiess et al. 1999).
In female mice, Insl 3 transcripts are first detected at day 6 after birth in ovarian theca and luteal cells, with a likely involvement in follicle development (Balvers et al. 1998). In adult women, INSL3 is detected in ovarian theca cells of large antral follicles and in the corpora lutea during the reproductive cycle and in pregnancy, and INSL3 serum levels are higher in adult men than in children or post-pubertal women (Büllesbach et al. 1999).

A genetic lack of INSL3 causes cryptorchidism - a developmental disorder involving failure of testis descent associated with defective spermatogenesis and infertility, and a high risk of testicular malignancy (Hutson et al. 1997). INSL3 normally induces growth and 
differentiation of gubernacula during the initial transabdominal movement of the testes (Hutson et al. 1997, Adham et al. 2000). Male mice homozygous for a disruption of the Insl3 gene exhibit bilateral cryptorchidism (Nef \& Parada 1999, Zimmermann et al. 1999), while female homozygotes display impaired fertility with abnormal oestrous cycles (Nef \& Parada 1999). In contrast, transgenic overexpression of Insl3 causes ovaries to descend into the inguinal region due to an overdeveloped gubernaculum (Adham et al. 2002).

Recent data have demonstrated that the native receptor for INSL3 is the type C leucine-rich repeat-containing G-protein-coupled receptor 8 (LGR8) (Hsu et al. 2002, Kumagai et al. 2002) (known also as RXFP2; see Bathgate et al. 2005 for review). INSL3 bound with high affinity to LGR 8 and receptor activation by INSL3 was associated with cAMP signalling. LGR 8 mRNA was detected in human gubernaculum and treatment of gubernacular cells with INSL3 stimulated cAMP production and thymidine incorporation (Kumagai et al. 2002). Transgenic mice with a deletion of Lgr8 (also known as Great) exhibit cryptorchidism (Overbeek et al. 2001), a phenotype identical to Insl3-deficient mice (see Bogatcheva et al. 2003). Furthermore, analysis of human INSL3 and LGR 8 mutations confirms cryptorchidism has a genetic aetiology related to these genes and INSL3-LGR 8 signalling (Ferlin et al. 2003).

Importantly, LGR 8 mRNA has been detected in a number of human tissues besides the gubernaculum, including ovary, testis, uterus, brain and kidney (Hsu et al. 2002). Until recently though, little has been published on the regional and cellular distribution of LGR8 expression or the functional role of INSL3 in these tissues of humans or other species (Kawamura et al. 2004). In an attempt to further elucidate the biology of the INSL3-LGR 8 system in the rat, we cloned and sequenced rat $\operatorname{Lgr} 8 \mathrm{cDNA}$ and screened various tissues for $\operatorname{Lgr} 8$ mRNA expression using RT-PCR (Scott et al. 2005). Based on these initial findings, we employed in situ hybridization histochemistry to localize $\operatorname{Lgr} 8$ expression in adult rat kidney and subsequently examined the temporal and spatial expression profile during development, using in situ hybridization histochemistry and quantitative real-time PCR. Results revealed L $g r 8$ mRNA associated with mature glomeruli during development and in adulthood, and subsequent autoradiographic studies with ${ }^{125}$ I-labelled human INSL3 revealed specific binding sites associated with glomeruli in renal cortex. Therefore, using primary cultures of renal glomerular cells isolated from rat kidney (containing mesangial and other cell types), we identified $\operatorname{Lgr} 8 \mathrm{mRNA}$ expression in these cells by RT-PCR analysis and examined the effect of INSL3 treatment on their viability. (A preliminary account of some of these findings appeared in a monograph on the proceedings of the Relaxin 2004 Conference (Fu et al. 2005)).

\section{Materials and Methods}

\section{Animals}

All procedures were approved by the Howard Florey Institute Animal Welfare Committee and were performed in strict accordance with guidelines of the National Health and Medical Research Council of Australia. Adult and postnatal Sprague-Dawley rats were deeply anaesthetized with the inhalation anaesthetic, isoflurane (Isoflo; Abbott Australia, Sydney, NSW, Australia) and then decapitated. Kidneys and other tissues were rapidly removed, frozen over liquid nitrogen and stored at $-80^{\circ} \mathrm{C}$ (see details below).

\section{Database search, rat Lgr8 sequence amplification and alignment}

As described briefly elsewhere, the protein sequence of human LGR8 (Accession No. NP_570718) was used to screen the National Center for Biotechnological Information (NCBI) high-throughput genome sequences (HTGSs) and fragmented hits were assembled through homology comparison with human LGR8 (Scott et al. 2005). Oligonucleotide primers based on the identified rat sequences were used to generate the full-length coding region via RT-PCR. Total RNA was extracted from dissected, snap-frozen rat tissues (testis, ovary, brain, kidney and embryonic day (E) 16 fetal gubernaculum) by homogenization in RNAwiz (Ambion Inc, Austin, TX, USA) and cDNA was synthesized from $2.5 \mu \mathrm{g}$ of total RNA using an RT-kit (Promega) and random hexamer primers. Putative LGR8-coding regions were amplified from cDNA, using a Taq polymerase PCR kit (Eppendorf, Sydney, NSW, Australia), cloned into the pGEM-T vector (Promega) and confirmed using Big Dye Terminator sequencing (Applied Biosystems, Foster City, CA, USA). The full coding sequence was assembled from overlapping fragments and confirmed by RT-PCR, using primers from outside the coding region. Alignment of human, mouse and rat sequences was done using ClustalW (http://www.ebi.ac.uk/clustalw/) and Boxshade 3.21 (http://www.ch.embnet.org/software/BOX_form.html) (Scott et al. 2005).

Detection of Lgr8 $m R N A$ in rat tissues and glomerular cells by RT-PCR

Rat tissues and samples of cultured rat glomerular cells were screened for Lgr8 mRNA expression using RT-PCR, as described (Kubota et al. 2002). Briefly, total RNA was extracted with RNAWiz reagent (Ambion Inc) according to the manufacturer's instructions. Primers equivalent to nucleotides $1338-1358$ and $2121-2141$ of the final rat $\operatorname{Lgr} 8 \mathrm{cDNA}$ sequence were used for RT-PCR reactions. The expression of glyceraldehyde-3-phosphate dehydrogenase (GAPDH) mRNA was used as a control 
for the quality of the cDNA synthesis and was amplified using primers equivalent to nucleotides 789-808 and 1017-1036 of rat GAPDH cDNA (Accession No. NM_017008). All the primers were designed to cross intron-exon boundaries to control for genomic DNA contamination.

\section{In situ hybridization histochemistry}

Frozen kidney sections $(14 \mu \mathrm{m})$ from both developing (E16, E18, postnatal day (P) 2, 5, 10, 20, 30 and 40, $n \geq 3$ for each age group) and adult rats were cut on a cryostat at $-16{ }^{\circ} \mathrm{C}$ and thaw-mounted onto microscope slides coated with $0 \cdot 2 \%$ poly-L-lysine $\left(M_{\mathrm{r}} 300000\right)$. Slides were stored at $-80{ }^{\circ} \mathrm{C}$ until use. Lgr8 mRNA was detected with three synthetic oligonucleotide probes corresponding to nucleotides 181-219, 1371-1409 and 2018-2056 of rat $\operatorname{Lgr} 8$ cDNA sequence. Probes were labelled with $\left[\alpha-{ }^{35}\right.$ S $]$ dATP $\quad(\geq 1200 \mathrm{Ci} / \mathrm{mmol} ;$ Perkin-Elmer Life Sciences, Melbourne, VIC, Australia) using terminal deoxynucleotidyl transferase (Roche Diagnostics) to a specific activity of $1-2 \times 10^{9}$ d.p.m. $/ \mu \mathrm{g}$. Sections were hybridized as described (Shen \& Gundlach 1996, Wisden \& Morris 2002) and then exposed to Kodak Biomax film (Integrated Sciences, Sydney, NSW, Australia) for 4-5 weeks, or coated with nuclear emulsion (Ilford K5, diluted 1:1 with $\mathrm{dH}_{2} \mathrm{O}$; Ilford Imaging, Melbourne, VIC, Australia) and exposed for 20-25 weeks, prior to development, counterstaining with $0.01 \%$ thionin and analysis using bright- and dark-field microscopy. The specificity of the hybridization signal was assessed by confirming the similarity of hybridization patterns obtained with individual probes (data not shown) and hybridization in the presence of a 100-fold excess of unlabelled oligonucleotides.

\section{Photography and image production}

Digital images of film autoradiograms were produced using a Sony XC-77CE CCD video camera coupled to a Nikon 1:2·8, $55 \mathrm{~mm}$ lens and a light box, with MCID M2 software (Imaging Research Inc, St Catharines, OT, Canada). Digital micrographs of nuclear-emulsiondipped, counterstained sections were produced under bright- and dark-field illumination on an Olympus IX70 microscope (Olympus Imaging, Melbourne, VIC, Australia) equipped with a SPOT real-time digital camera with Image-pro 4.5 software (Diagnostics Instruments, Sterling Heights, MI, USA). All micrographs were archived as high-resolution images in Adobe Photoshop (Version 5.0; Adobe Systems Inc, San Jose, CA, USA) and after any required cropping, adjustment for contrast or removal of obvious artefacts, plates were compiled and labelled in PowerPoint (Microsoft Corporation).

\section{Real time-PCR analysis of Lgr8 $m R N A$ in rat kidney}

Kidney tissue from embryonic, developing and adult rats was finely diced under liquid nitrogen and immediately homogenized with RNAWiz reagent (Ambion Inc.). Total RNA was extracted and real-time PCR was used to quantify $\operatorname{Lg} r 8 \mathrm{mRNA}$ levels in each sample. Real-time PCR primers and probes were designed using Primer Express (Applied Biosystems). The primer sequences are located at nucleotides 1898-1917 and 1998-1977 of the Lgr8 cDNA respectively and span a $9.0 \mathrm{~kb}$ intron. Total RNA $(1 \mu \mathrm{g})$ from each sample was used for the RT, in a $30 \mu \mathrm{l}$ reaction (Siebel et al. 2002). The probe sequence, corresponding to nucleotides 1925-1961, was labelled at the $5^{\prime}$-end with 6-carboxy fluorescein (Qiagen) and included with the primers in each reaction tube. The relative $\mathrm{C}_{\mathrm{T}}$ standard curve method was adopted and ribosomal RNA (18S) was used as an internal, endogenous control, with primers and probe(s) as described (Siebel et al. 2002).

\section{${ }^{125}$ I-INSL3 autoradiography}

${ }^{125}$ I-Human INSL3 binding autoradiography was performed essentially as described in earlier studies with ${ }^{33} \mathrm{P}-$ labelled human relaxin (Burazin et al. 2002). Slidemounted cryostat sections $(14 \mu \mathrm{m})$ of kidney were preincubated in $25 \mathrm{mM}$ Hepes, $5 \mathrm{mM} \mathrm{MgCl}, \mathrm{pH} 7 \cdot 2$ for $30 \mathrm{~min}$. Slides were then incubated in the same buffer plus $0 \cdot 1 \%$ BSA (w/v), $0 \cdot 015 \%$ Pefabloc (w/v) and $100 \mathrm{pM}$ ${ }^{125}$ I-human INSL3 (Perkin-Elmer Life Sciences) at $21{ }^{\circ} \mathrm{C}$ for $1 \mathrm{~h}$. Non-specific binding was determined by the addition of $100 \mathrm{nM}$ unlabelled human INSL3 (Fu et al. 2004) to the incubation buffer. Following incubation, slides were washed twice for $5 \mathrm{~min}$ each in ice-cold incubation buffer and rinsed in ice-cold $\mathrm{d}_{2} \mathrm{O}$. Sections were allowed to air-dry overnight and were apposed to Kodak Biomax film for 5 days.

\section{Rat glomerular cell culture}

Male Sprague-Dawley rats $(n=12$ per study) were anaesthetized using Isoflo and kidneys were rapidly removed and placed on ice. Renal cortical tissue was excised and minced with a razor blade into millimetresized pieces. Glomeruli were isolated by passing the minced cortex through a $150 \mu \mathrm{m}$ steel sieve and collecting strained material on a $75 \mu \mathrm{m}$ steel sieve. Intact glomeruli were removed from the sieve, rinsed twice in PBS and centrifuged at $400 \boldsymbol{g}$ for $5 \mathrm{~min}$. Glomeruli were resuspended and incubated with $0 \cdot 1 \%$ collagenase $(190 \mathrm{U} / \mathrm{ml})$ at $37^{\circ} \mathrm{C}$ for $30 \mathrm{~min}$. After incubation, cells were centrifuged and the pellet was washed twice with PBS. Cells were then plated onto two $60 \mathrm{~mm}$ dishes in DMEM medium supplemented with $20 \%$ fetal calf serum, 
$2 \mu \mathrm{M}$ glutamine, $5 \mu \mathrm{g} / \mathrm{ml}$ insulin, $100 \mathrm{U} / \mathrm{ml}$ penicillin, $100 \mu \mathrm{g} / \mathrm{ml}$ streptomycin (culture medium) in a 95\% air-5\% $\mathrm{CO}_{2}$ humidified atmosphere at $37^{\circ} \mathrm{C}$ (Gruden et al. 1997).

\section{Glomerular cell viability/proliferation assay}

Glomerular cell samples, likely to be enriched in mesangial cells but also containing endothelial and epithelial cells, were seeded into 96-well plates at a density of $1 \times 10^{4}$ cells/well in culture medium in a $95 \%$ air $-5 \%$ $\mathrm{CO}_{2}$ humidified atmosphere at $37^{\circ} \mathrm{C}$. After a $24 \mathrm{~h}$ incubation, the medium was replaced by serum-free medium containing $0 \cdot 1 \%$ BSA and INSL3 or other peptide. Cells were incubated for a further $48 \mathrm{~h}$ and then cell viability/proliferation was assessed by an MTT assay (Hansen et al. 1989, Loveland et al. 1992). Briefly, MTT reagent (3-(4,5-dimethylthiazol-2-yl)-2,5-diphenyl tetrazolium bromide; final concentration $0.5 \mu \mathrm{g} / \mathrm{ml}$ ) was added, the cells were incubated for $3 \mathrm{~h}$ and then the insoluble reaction product was dissolved by the addition of $100 \mu \mathrm{l}$ of cell lysis buffer $\left(20 \% \mathrm{w} / \mathrm{v}\right.$ SDS, $50 \% \mathrm{~N}, N^{\prime}-$ dimethyl-formamide). In several wells, cells were lysed by the addition of cell-lysis buffer immediately prior the addition of MTT, to control for background absorbance. Absorbance of each well was measured at $595 \mathrm{~nm}$ using a Microplate Reader Model 3550-UV Spectrophotometer (Bio-Rad Laboratories). Data are expressed as a percentage of the maximum control response \pm S.D. from three to five independent experiments. Statistical differences were assessed using one-way ANOVA.

\section{Results}

\section{Cloning, sequencing and tissue distribution of rat $\mathrm{Lgr} 8$}

In preliminary studies, rat Lgr8 gene was cloned and sequenced (see Scott et al. 2005) and subsequently its distribution in different rat tissues was explored by RTPCR. Briefly, sequences homologous to regions of the human $L G R 8$ cDNA were identified in bacterial artificial chromosome clones in the NCBI HTGS database. Using derived, specific RT-PCR primers the full rat $\operatorname{Lgr} 8 \mathrm{cDNA}$ was assembled by sequencing multiple, independent overlapping clones from E16 fetal rat gubernaculum (Genebank Accession No. AY906861). Cells transfected with full-length rat LGR 8 demonstrate high-affinity binding for ${ }^{125}$ I-INSL3 3 and respond to ligand stimulation with cAMP accumulation (Scott et al. 2005). RT-PCR analysis of rat tissues revealed strong $\operatorname{Lgr} 8$ expression in gubernaculum, testis and ovary (data not shown; Kawamura et al. 2004). Notably, $\operatorname{Lgr} 8 \mathrm{mRNA}$ was also found in rat brain (Shen et al. 2005) and kidney (Fu et al. 2005; this study).
Detection of regional and cellular Lgr8 $m R N A$ expression in adult and developing kidney

In an attempt to discover the regional and cellular distribution of these receptors in rat kidney, frozen longitudinal sections from adult (8- to 10-week-old) male rats were subjected to in situ hybridization histochemistry for $\operatorname{Lgr} 8$ mRNA using ${ }^{35}$ S-labelled oligonucleotides. Relatively low-resolution film autoradiograms revealed the expression of $\operatorname{Lgr} 8 \mathrm{mRNA}$ restricted to the renal cortex, in a pattern consistent with labelling of cells within the glomeruli (Fig. 1A). The specificity of the Lgr8 mRNA signal detected was confirmed by several methods. In competition experiments, the signal was abolished when a 100-fold excess of unlabelled oligonucleotides was added to the incubation (Fig. 1 $\mathrm{A}^{\prime}$ ). Secondly, sections hybridized with the three individual oligonucleotide probes displayed the same distribution of labelling (data not shown), and finally the oligonucleotide probes used produced strong, specific labelling of sections of gubernaculum from a 17-day rat embryo and adult testis (data not shown; Scott et al. 2005). Microscopic analysis of high-resolution nuclear emulsion autoradiograms from counterstained kidney sections indicated that $\operatorname{Lgr} 8$ mRNA expression was restricted to putative mesangial cells within the adult glomeruli (Fig. 1B and C), with no obvious specific hybridization observed in glomerular podocyte or epithelial cells (Hoffmann et al. 2004). Notably, parallel in situ hybridization studies with Lgr7-directed oligonucleotides (Burazin et al. 2005) failed to detect $\operatorname{Lgr} 7 \mathrm{mRNA}$-positive cells in rat kidney (data not shown).

\section{Profile of Lgr8 mRNA expression during embryonic and postnatal development}

Subsequent to the identification of cell-specific expression in adult kidney, we assessed the possible renal expression of $\operatorname{Lgr} 8 \mathrm{mRNA}$ in samples of developing kidney to provide further possible insights into the functional involvement of LGR8. In these studies the profile of L $\mathrm{gr} 8$ expression during fetal and postnatal kidney development was examined by in situ hybridization and quantitative real-time RT-PCR. Although expression of Lgr8 was detectable in frozen sections from E16 through to adulthood, highest relative levels were observed in the embryonic stages, around E18 (Fig. 2). Shortly after birth at P2-5, a sharp decrease in Lgr 8 mRNA levels was observed and the reduction continued until $\operatorname{Lgr} 8$ transcripts reached their lowest level in adult kidney (Fig. 2). Kidney sections from $\mathrm{P} 2$ rats, in which glomerulogenesis is still occurring, displayed strong Lgr8 expression in mature glomeruli, whereas little or no distinct signal was observed in immature glomeruli or the nephrogenic zone, located at the edge of the renal cortex (Fig. 3A-A"). In P10 kidney, the nephrogenic zone is absent as glomerulogenesis has 

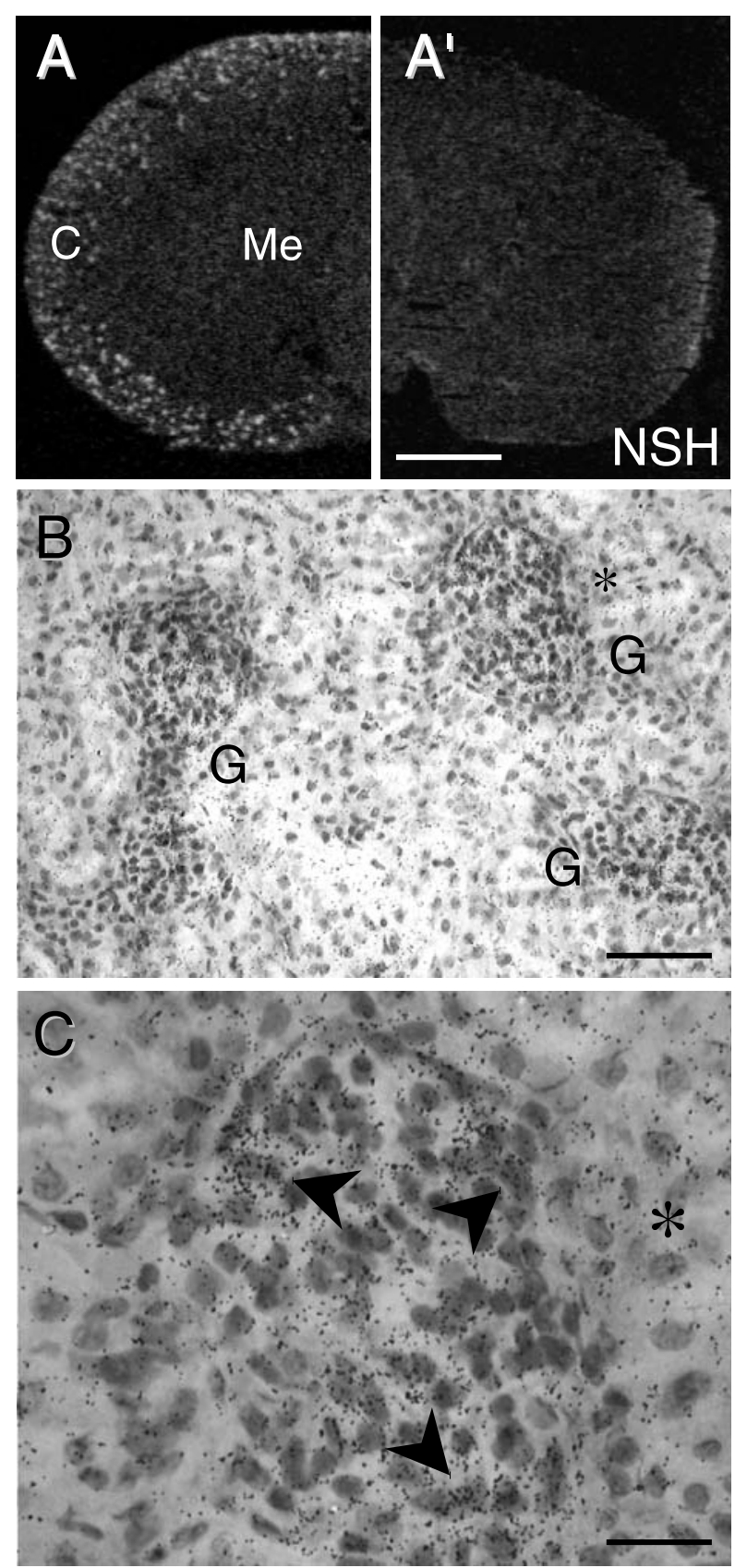

Figure 1 Regional and cellular distribution of Lgr8 mRNA in frozen sections of adult kidney from male rats. (A) In situ hybridization of ${ }^{35}$ S-labelled oligonucleotide probes revealed that Lgr8 mRNA was present in renal cortex $\left({ }^{\prime} C^{\prime}\right)$ in a specific pattern consistent with an association with glomeruli, while no hybridization signal was detected in the renal medulla ('Me'). ( $\mathrm{A}$ ') In a competition experiment, the hybridization signal was eliminated by a 100 -fold excess of unlabelled oligonucleotides added to the hybridization mixture containing labelled probes, leaving only 'non-specific hybridization' ('NSH'). (B) Nuclear-emulsion autoradiograms confirmed that Lgr8 mRNA was associated with cortical glomeruli $\left(' \mathrm{G}^{\prime},{ }^{*}\right)$. (C) At high magnification, Lgr8 mRNA-associated grains were observed over individual cells putatively identified as mesangial cells. Scale bar $=2.5 \mathrm{~mm}\left(\mathrm{~A}, \mathrm{~A}^{\prime}\right) ; 7.5 \mu \mathrm{m}(\mathrm{B}) ; 2.5 \mu \mathrm{m}(\mathrm{C})$. been completed by this age and $\operatorname{Lgr} 8$ expression is abundant in mature glomeruli (Fig. 3B-B"). At all stages of nephron development studied, Lgr8 expression appeared to be restricted to cells of mature glomeruli and was not detected in any other tissue regions or cell types.

Quantitative real-time PCR was also used to measure renal Lgr8 mRNA levels at different developmental stages and confirmed that Lgr8 expression was high in embryonic stages and decreased during postnatal kidney development. The PCR primers used cross a large intron of $9 \cdot 5 \mathrm{~kb}$ to prevent genomic DNA contamination and $18 \mathrm{~S}$ ribosomal mRNA was used as a control for quantification of RNA amount. Total RNA isolated from E18, P2, 5, 10,20 and 60 (adult) kidneys was analysed $(n=4-5$ rats per time). Highest levels of Lgr8 mRNA expression were detected in E18 kidney and relatively high levels were also observed at P2, before being significantly decreased by 4-fold at P5 (Fig. 4A). There was no significant change in Lgr 8 mRNA levels between P5 and 10, but at P20 the levels were 12-fold lower than at P2. By adulthood, there was a further reduction in $\mathrm{Lgr} 8 \mathrm{mRNA}$ levels representing a 48-fold decrease in $\operatorname{Lgr} 8 \mathrm{mRNA}$ expression from P2. Lgr 8 transcript levels measured at P20 and adulthood were also significantly lower than those measured at P5 and 10 (Fig. 4A). Notably, parallel RT-PCR studies failed to detect Insl3 mRNA in embryonic, postnatal or adult kidney, despite effective detection of high levels of transcripts in adult testis, as a positive control for the primers and protocol used (data not shown).

\section{Renal Lgr8 expression in male and female rats}

INSL3 has to date been largely considered as a male hormone and investigated for its capacity to stimulate gubernaculum growth and differentiation during the process of testicular descent. The serum concentration of INSL3 is lower in adult females that males in various species (Büllesbach et al. 1999, Boockfor et al. 2001), but INSL3 is also produced by tissues such as the ovary (Büllesbach et al. 1999). Comparison of levels of Lgr8 mRNA in adult male and female kidney by quantitative real-time RT-PCR analysis revealed that Lgr8 mRNA levels were some 6-fold higher in the female than male (Fig. 4B).

\section{Detection of ${ }^{125}$ I-INSL3-binding sites in developing and adult kidney}

In studies aimed at revealing the presence and distribution of functional LGR8 in rat kidney, frozen longitudinal sections from adult and developing rats were incubated with ${ }^{125}$ I-human INSL3. Specific ${ }^{125}$ I-INSL3-binding sites were detected by X-ray film autoradiography in the renal cortex, in a pattern consistent with labelling of cells within the glomeruli (Fig. 5A). The specificity of the binding detected was confirmed by its inhibition in the 

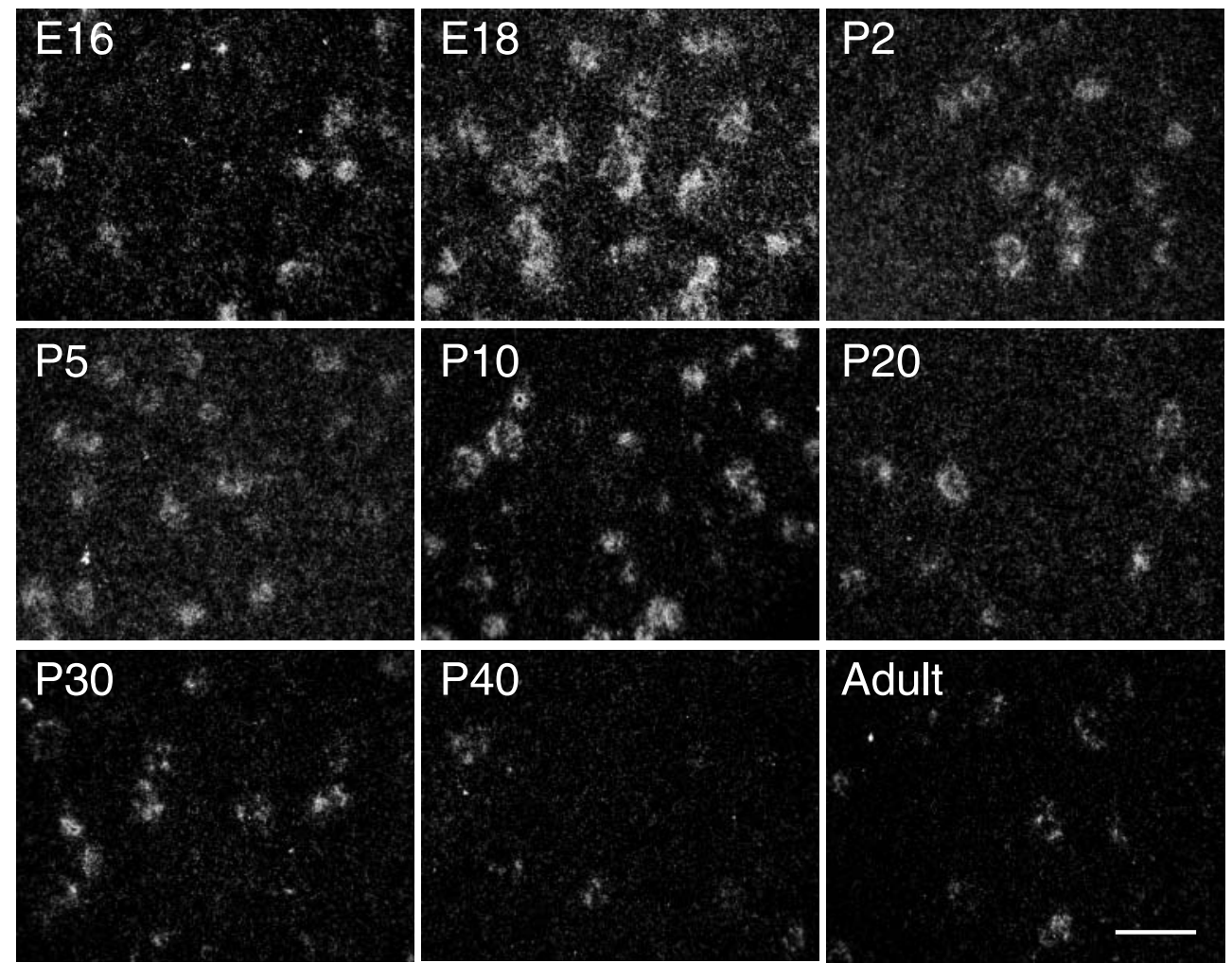

Figure 2 Relative abundance of Lgr8 mRNA in rat kidney at different stages of development, determined by in situ hybridization. Representative dark-field images of nuclear-emulsion autoradiograms reveal the presence of Lgr8 mRNA at all ages examined, with the strongest hybridization observed during late stages of embryonic gestation at E18 and a stronger signal in P2-P10 than in more mature (P20, P40) and adult kidney. Scale bar $=500 \mu \mathrm{m}$.

presence of $100 \mathrm{nM}$ unlabelled human INSL3 (Fig. 5B). In addition, specific binding was also detected in renal cortex (glomeruli) of kidney from postnatal rats (Fig. 5C-H), indicating the presence of functional LGR8 throughout this period. In kidney sections from P2-5 rats, in which very strong $\operatorname{Lgr} 8 \mathrm{mRNA}$ expression was detected, ${ }^{125}$ I-INSL3-binding densities associated with glomeruli were lower than those seen in more mature rats (Fig. 5C-H).

Primary cultured glomerular cells express Lgr8 $m R N A$

In studies aimed at examining the presence of functional renal LGR8, adult rat glomerular cells were isolated and cultured under standard conditions (e.g. Gruden et al. 1997; see Methods). Cells were propagated in culture and passaged a total of ten times before total RNA from these cells was isolated and subjected to RT-PCR analysis for Lgr 8 mRNA. The predicted 101 bp band specific for $\operatorname{Lg} r 8$ was detected, while under the same conditions no $\operatorname{Lgr} 7$ mRNA expression was detected in these cells (Fig. 6). The housekeeping gene encoding GAPDH RNA was used as a control for sample RNA content/lane loading.
Total RNAs isolated from kidney, E17 gubernaculum and cervix were used as positive controls for $\operatorname{Lgr} 8$ and $\operatorname{Lgr} 7$ expression. In contrast to in situ hybridization studies, weak expression of $\operatorname{Lgr} 7 \mathrm{mRNA}$ was detected in whole kidney by RT-PCR (Fig. 6), possibly associated with expression by the renal vasculature (Danielson et al. 1999).

\section{INSL3 inhibits proliferation of rat glomerular cells}

Glomerular cells were incubated in serum-free medium containing $0 \cdot 1 \%$ BSA to assay cell viability and proliferation and treatment with $10 \mathrm{nM}$ INSL3 for $48 \mathrm{~h}$ resulted in a $25 \%$ decrease in cell proliferation $(P<0 \cdot 01$; Fig. $7 \mathrm{~A})$. In contrast, treatment of these cells with another insulin/ relaxin family peptide, INSL4 (10 nM), had no significant effect on cell numbers. Human relaxin, which has been shown to bind to LGR8 transfected into human fetal kidney fibroblast 293T cells and induce cellular cAMP accumulation, had no effect on cell proliferation at $10 \mathrm{nM}$, but a $100 \mathrm{nM}$ concentration produced an $\sim 15 \%$ decrease $(P<0 \cdot 05$; Fig. 7A), consistent with a loweraffinity interaction with LGR 8 than INSL3. The effect of INSL3 was also shown to be dose-dependent (Fig. 7B), 

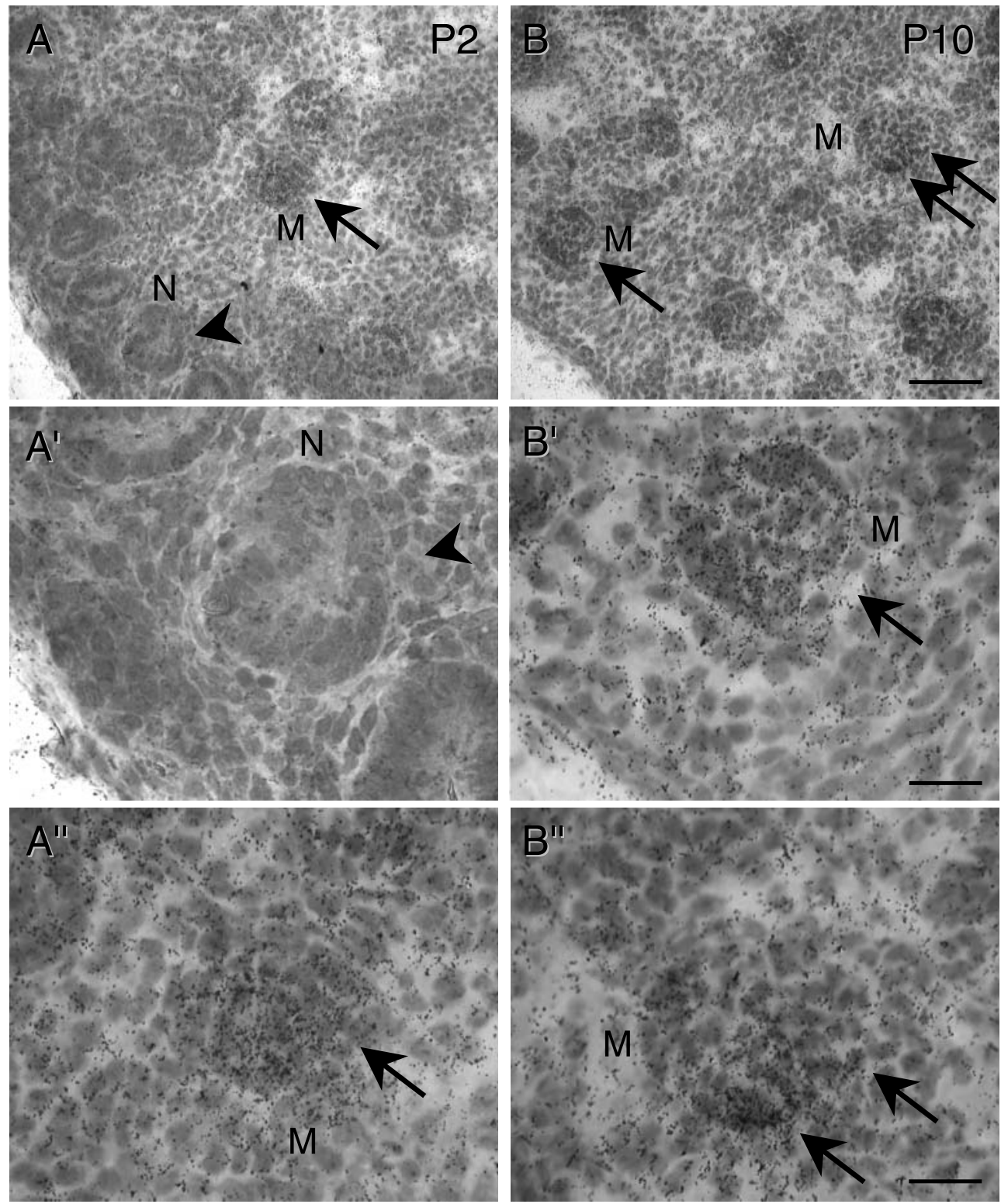

Figure 3 Regional localization of Lgr8 mRNA in rat kidney at different ages of development, determined by in situ hybridization. (A-A") In P2 kidney, high densities of Lgr8 mRNA-associated silver grains were observed over mature glomeruli $\left(\mathrm{A}^{\prime \prime}, \mathrm{M}^{\prime}\right.$, arrow) situated in the deeper part of the cortex, but transcripts were absent in the nephrogenic zone ( $\mathrm{A}^{\prime}, \mathrm{N}^{\prime}$ ', short arrow). (B- $\left.\mathrm{B}^{\prime \prime}\right)$ In P10 kidney, the nephrogenic zone has disappeared, as glomerulogenesis has been completed by this age and Lgr8 mRNA is abundant in mature glomeruli throughout the cortex $\left(B^{\prime}, B^{\prime \prime},{ }^{\prime}{ }^{\prime}\right.$, single/double arrows). Scale bar $=7.5 \mu \mathrm{m}(A, B) ; 2.5 \mu \mathrm{m}$ $\left(A^{\prime}, A^{\prime \prime}, B^{\prime}, B^{\prime \prime}\right)$.

with an approximate $\mathrm{IC}_{50}$ between 1 and $10 \mathrm{nM}$. There is a possibility that INSL3 and the other peptides added to the incubation may have had differential or separate effects on the different cell types present in the mixed culture that may have biased the results observed and further specific tests are required to determine whether INSL3 promotes apoptosis in this system, but otherwise these data indicate that INSL3 is a specific and potent inhibitor of renal cell proliferation.

\section{Discussion}

In an important step towards better understanding the nature of INSL3 action in different organs, in the current 

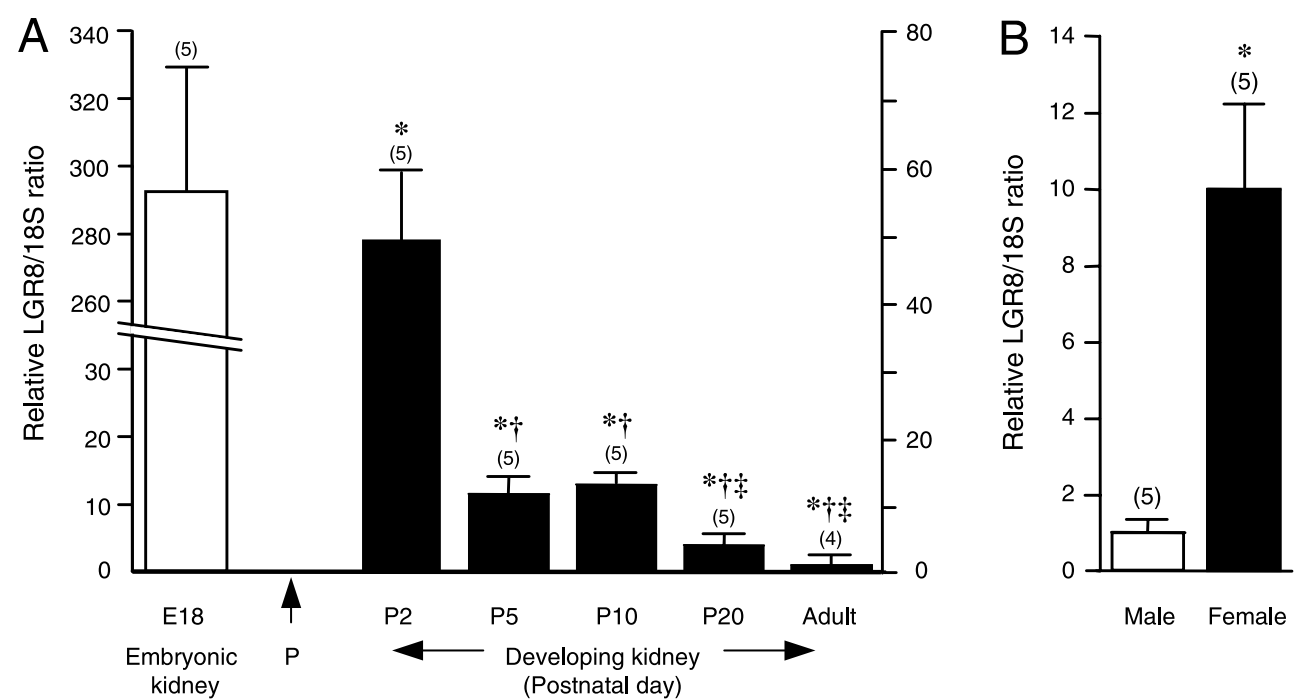

Figure 4 Quantitative real-time PCR analysis of Lgr8 mRNA levels in rat kidney during development and in male and female rats. (A) Relative Lgr8 mRNA levels in embryonic kidney (E18) and postnatal kidney (P2, 5, 10, 20 and 60 (adult)). Data were normalized to their $18 \mathrm{~S}$ ribosomal RNA values, and then expressed relative to Lgr8 expression in the adult group, which was represented as $1 \cdot 0$. Note the different scales used to graph embryonic, postnatal and adult data. Values represent means \pm S.E.M. $(n=4-5$ rats/age group). ${ }^{*} P \leq 0.05$ compared with E18; $\uparrow P \leq 0.05$ compared with $\mathrm{P} 2 ; \neq P<0.05$ compared with $\mathrm{P} 5$ (and P10) (one-way ANOVA). (B) Comparison of $\operatorname{Lgr} 8$ mRNA levels in adult male and female kidneys, with mRNA levels in the male group represented as $1 \cdot 0$. Values represent means \pm S.E.M. $\left(n=5\right.$ rats). ${ }^{\star} P<0 \cdot 05$ (one-way ANOVA).

studies we have identified the regional and cellular expression pattern of LGR8 in adult and developing rat kidney, and conducted some preliminary in vitro studies of INSL3 actions on LGR8-positive renal cells. As we reported briefly elsewhere (Scott et al. 2005), rat Lgr8 has a high degree of sequence and structural identity with its counterpart human and mouse receptors (Hsu et al. 2002, Scott et al. 2004). Human INSL3 is a high-affinity ligand for rat LGR8, binding and activating cAMP signalling with a similar affinity/efficacy to that at the human LGR8, and native rat relaxin is not a ligand for rat LGR8 (Scott et al. 2005). RT-PCR analysis identified $\operatorname{Lgr} 8 \mathrm{mRNA}$ expression in rat fetal gubernaculum, brain, testis, ovary and kidney, but not in the liver. Expression in the E16 gubernaculum highlights the essential role that INSL3 plays in testis descent (Bogatcheva \& Agoulnik 2005), while expression in the ovary and testis confirms the important role that INSL3 plays in germ cell maturation in male and female rats (Kawamura et al. 2004). Expression of LGR8 in rat kidney and brain and studies of the putative INSL3-LGR 8 systems in these tissues is also of interest (see Fu et al. 2005, Shen et al. 2005).

In situ hybridization studies with ${ }^{35} \mathrm{~S}-$ labelled oligonucleotides consistently and exclusively detected $\mathrm{Lgr} 8$ mRNA in mature glomeruli (possibly in mesangial cells) during development and in adulthood. Levels of renal Lgr8 mRNA expression were also quantified at various stages of kidney development by real-time PCR, with highest levels detected at E18 and expression observed at all times studied. Radioligand binding studies with ${ }^{125}$ I-INSL3 confirmed the presence of somewhat differing levels of functional LGR 8 binding sites in renal glomeruli during development and in adulthood. These anatomical findings were extended by in vitro studies that revealed that cultured glomerular cells isolated from adult kidney expressed $\operatorname{Lgr} 8$ transcripts and that treatment of these cells with INSL3 reduced their number by inhibiting proliferation (or promoting apoptosis?). These data indicate that functional LGR8 (receptors) might be present on mesangial cells and/or on endothelial and epithelial cells, and is consistent with the abundant, specific expression of LGR 8 by cells in mature glomeruli in embryonic, early postnatal and adult kidney. It suggests a potentially important role for INSL3-LGR 8 signalling in regulating the development, maturation and/or normal function of these renal cells in rat and possibly other species, including mouse and human.

Glomerulogenesis involves four major cellular processes - migration, proliferation, differentiation and apoptosis. Active migration, proliferation and differentiation of mesangial cells occur largely in immature glomeruli. Glomerular mesangial cells are, however, known to have a limited capacity for proliferation and cease to proliferate when mature glomeruli are formed. In normal adult kidney, the turnover rate of mesangial cells is $1 \%$ per day (Pabst \& Sterzel 1983). The Lgr8/LGR8 expression pattern 

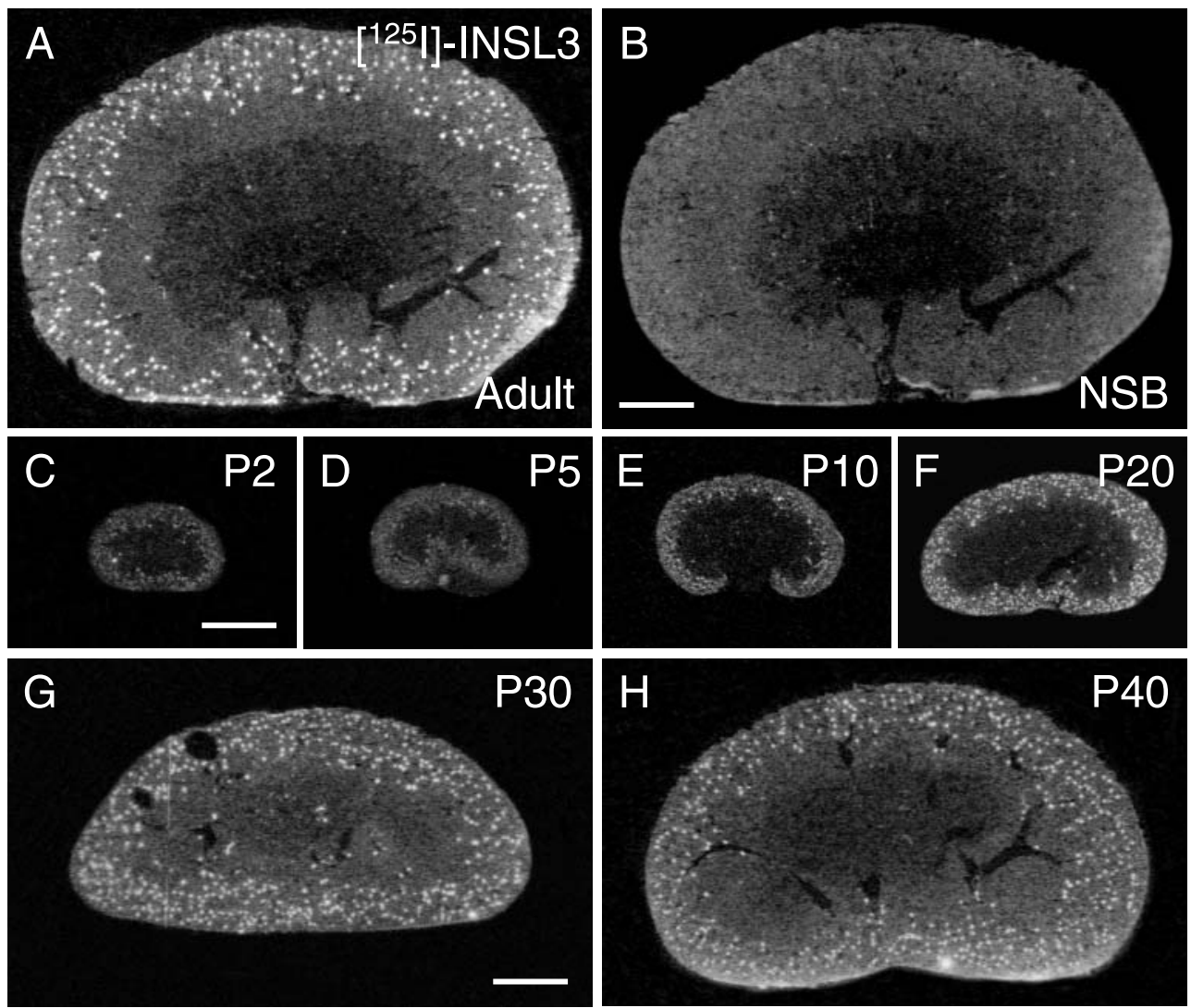

Figure 5 Distribution of ${ }^{125}$ I-INSL3-binding sites in adult and postnatal rat kidney. $(\mathrm{A}-\mathrm{H})$ Representative X-ray film autoradiograms of ${ }^{125}$ I-INSL3-binding sites in longitudinal sections of kidney from male rats reveal the presence of presumed LGR8 in the renal cortex in both adult $(\mathrm{A})$ and postnatal kidney $(\mathrm{C}-\mathrm{H})$ in a pattern consistent with an association with glomeruli and with the distribution of Lgr8 mRNA. No specific ${ }^{125}$ I-INSL3 binding was observed in the renal medulla at any age. (B) Addition of $100 \mathrm{nM}$ unlabelled human INSL3 to the incubation abolished all specific ${ }^{125}$ I-INSL3 binding, leaving only low levels of non-specific binding (NSB). Scale bar $=3 \mathrm{~mm}(\mathrm{~A}-\mathrm{H})$.

observed is very similar to that for the angiotensin II receptor-1 (Harrison-Bernard et al. 1997, Norwood et al. 1997, Ma et al. 2004), with both mRNAs/proteins highly expressed in mature glomeruli (possibly by mesangial cells), but not in more immature comma- or S-shaped bodies - implying that like angiotensin II, INSL3 is more likely to be involved in the inhibition of mesangial cell proliferation and/or apoptosis during glomerulogenesis, than in differentiation and/or migration (Ma et al. 2004). This speculation is supported by the current in vitro experiments in which treatment of cultured glomerular cells (enriched in mesangial cells) with synthetic INSL3 resulted in apparent inhibition of proliferation, suggesting that like transforming growth factor- $\beta$ (TGF- $\beta$ ) (Jaffer et al. 1989), INSL3 (circulating) is a growth-inhibitory factor for these renal cells.

Glomerular mesangial cells play an important role in maintaining the structure/function of the capillary ultrafiltration apparatus. Maintaining the correct number of

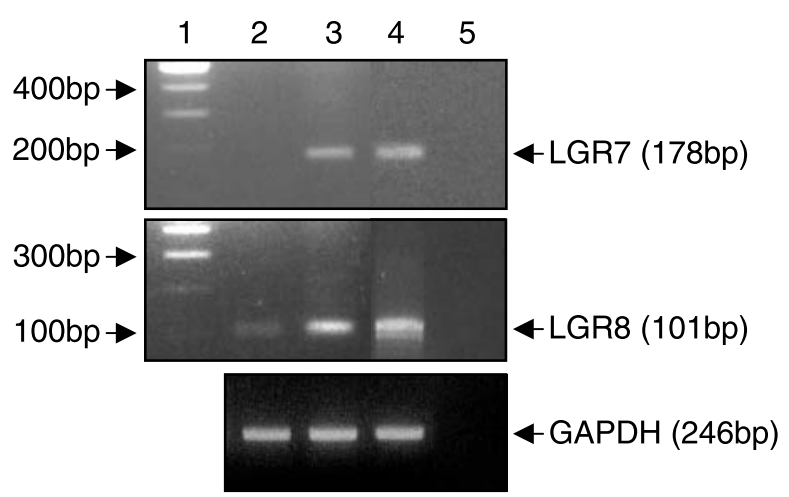

Figure 6 Lgr8 mRNA expression in cultured glomerular cells from adult rat kidney. RT-PCR analysis of total RNA isolated from cultured cells of rat kidney revealed the presence of Lgr8 mRNA. Lane 1: 100 bp DNA ladder; lane 2: glomerular cell extract; lane 3: whole kidney tissue; lane 4: positive controls (cervix - Lgr7 (upper); gubernaculum - Lgr8 (lower); lane 5: negative control (water as template). Expression of GAPDH mRNA was used as a control for the quality of the cDNA synthesis. 

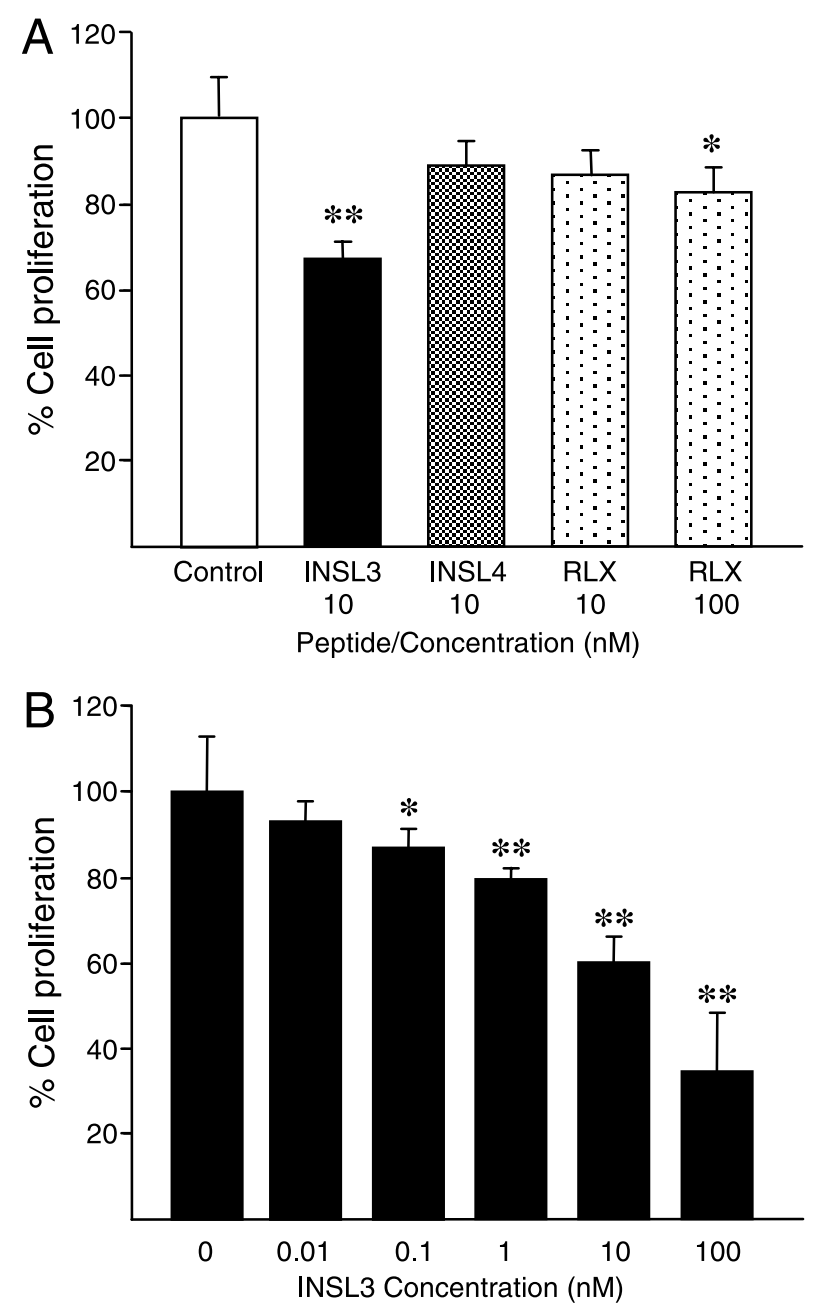

Figure 7 INSL3-induced inhibition of the proliferation of rat glomerular cells. Cells were cultured in 96-well microplates for $48 \mathrm{~h}$ in serum-free medium supplemented with $0 \cdot 1 \%$ BSA and with various test peptides. Effects of treatment with INSL3 or other peptides were analysed using an MTT assay, as described in Materials and Methods. (A) Effect of INSL3, INSL4 and relaxin (RLX) on cell proliferation. Values (each bar) represent means \pm S.D. $(n=3)$. (B) Dose-dependent inhibition of cell proliferation by INSL3. Values are means \pm S.D. $(n=5) .{ }^{*} P=0 \cdot 05 ;{ }^{*} P<0 \cdot 01$ (one-way ANOVA).

mesangial cells is important for renal physiology and abnormalities are associated with renal pathology. Thus, uncontrolled mesangial cell proliferation is a primary event leading to the pathogenesis of progressive renal diseases including diabetic nephropathy, membraneproliferative glomerulonephritis and lupus nephritis (Haas et al. 1999). Increased mesangial cell proliferation may also be essential for glomerular repair. Several growth factors and mediators can regulate mesangial cell proliferation, including platelet-derived growth factor (Blom et al. 2001), basic fibroblast growth factor (Floege et al. 1993), insulin-like growth factors (Feld et al. 1995) and TGF- $\beta$
(Jaffer et al. 1989). Among these, TGF- $\beta$ is the only peptide with anti-mitogenic and anti-inflammatory actions (Schoecklmann et al. 1997, 1999), but TGF- $\beta$ also plays an important role in the pathogenesis of glomerular disease and mediates extracellular matrix deposition leading to glomerulosclerosis (Shankland \& Johnson 1998). Nonetheless, the possibility that INSL3 inhibits mesangial cell proliferation (and/or promotes apoptosis) predicts a potentially beneficial application of the INSL3-LGR8 system in glomerular diseases, especially those involving excessive mesangial cell proliferation.

A characteristic action of INSL3 is to stimulate gubernacular cell proliferation and differentiation during testicular descent (see Introduction). LGR 8 transcripts are present in human gubernaculum and INSL3 stimulates cAMP production and thymidine incorporation in cultured E17 gubernaculum (Kubota et al. 2002, Kumagai et al. 2002). In rat testis, however, INSL3 inhibits germ cell apoptosis (Kawamura et al. 2004). Thus, in rat kidney INSL3 may have a different function to that in gubernacular or germ cells - inhibiting cell proliferation. Such differential, cell-type specific effects have been observed for other peptide ligand-receptor systems, including members of the insulin/relaxin superfamily (Saile et al. 2004).

Expression of $\operatorname{Lgr} 8 \mathrm{mRNA}$ was 6-fold higher in female than male rat adult kidney. The serum INSL3 concentration is reportedly higher in adult men than in postpubertal women (Büllesbach et al. 1999) and higher in adult male rats than females (Boockfor et al. 2001). Whether the higher level of Lgr8 in female rat kidney reflects a biological compensation for the low level of INSL3 in female serum and is reflected by a correspondingly higher expression of LGR 8 protein in female kidney requires further investigation, along with studies of the precise relationship between gene and protein expression in renal glomeruli during development (in males and females). In this respect it is possible that levels of ${ }^{125}$ I-INSL3 binding observed accurately reflect the densities of LGR 8 protein present in developing kidney or that binding levels are influenced by the level of endogenous ligand present in the tissue prior to its collection. The ratio of transcript to protein and the exact nature of the glomerular cells expressing LGR8 (mesangial or other?) might be better understood following the eventual development and application of specific antisera to rat LGR8. Nevertheless our current findings, along with the apparent absence of endogenous renal Insl3 expression, suggest that actions of circulating INSL3 at LGR8 may play a role in regulating both male and female kidney function.

Insl3- and Lgr8-deficient mice have been generated by several independent groups (Nef \& Parada 1999, Zimmermann et al. 1999, Overbeek et al. 2001, Kamat et al. 2004), but their investigations have not reported any phenotypic kidney abnormalities. This suggests that 
INSL3 may not be essential for mouse nephrogenesis, but at this stage some role for INSL3 in embryonic kidney development cannot be precluded. It is perhaps likely that other mediators can compensate for the lack of INSL3 and/or LGR 8 activity, but alternatively there may be some minor phenotypic changes in these knockout mice which have not been discovered. Interestingly, Nef \& Parada (1999) reported that mice lacking Insl3 produced a somewhat smaller average litter size, but it remains to be determined whether this is due to some germ cell abnormalities (Kawamura et al. 2004). Future studies in these insl3 - / - mice should allow clarification of the physiological role of the INSL3-LGR8 system in renal development and normal renal function. In this context, the distribution of LGR 8 should also be assessed in wild-type mouse kidney and compared with that in the rat.

\section{Conclusion}

These studies have demonstrated that functional receptors for INSL3 - LGR8 (RXFP2) - are expressed by mature glomeruli in developing and adult rat kidney in vivo and by glomerular cells in vitro, which suggests a potential role for INSL3-LGR8 signalling in the regulation of renal physiology. In particular, the presence of $\operatorname{Lgr} 8 \mathrm{mRNA}$ and specific INSL3-binding sites in mature glomeruli in embryonic kidney suggests that INSL3 is involved in glomerulogenesis and/or mesangial cell development, possibly by regulation of cell proliferation and/or apoptosis. Further studies are warranted to examine the effects of INSL3, and newly developed, high-affinity LGR 8 antagonists (Büllesbach \& Schwabe 2005), on kidney function in vivo and on various renal glomerular cell types in vitro, including studies of characterized mesangial cells, to provide a better understanding of INSL3 action on cell proliferation/survival.

\section{Acknowledgements}

The authors would like to thank Dr Marjorie Dunlop (Faculty of Medicine, The University of Melbourne, VIC, Australia) for advice on renal cell culture; Dr Tim Hewitson (Royal Melbourne Hospital, The University of Melbourne, VIC, Australia) for assistance and comments on the manuscript; Prof. John Hutson (Royal Melbourne Hospital, The University of Melbourne, VIC, Australia) for provision of rat gubernacular tissues; and Dr Yieh-Ping Wan (Perkin-Elmer Life Sciences, Boston, MA, USA) for radio-iodination of human INSL3.

\section{Funding}

This research was supported by grants from the National Health and Medical Research Council (NHMRC) of Australia and BAS Medical Inc, San Mateo, CA, USA.
The authors declare that there is no conflict of interest that would prejudice the impartiality of this scientific work.

\section{References}

Adham IM, Emmen JM \& Engel W 2000 The role of the testicular factor INSL 3 in establishing the gonadal position. Molecular and Cellular Endocrinology 160 11-16.

Adham IM, Steding G, Thamm T, Bullesbach EE, Schwabe C, Paprotta I \& Engel W 2002 The overexpression of the Insl3 gene in female mice causes descent of the ovaries. Molecular Endocrinology 16 244-252.

Balvers M, Spiess AN, Domagalski R, Hunt N, Kilic E, Mukhopadhyay AK, Hanks E, Charlton HM \& Ivell R 1998 Relaxin-like factor expression as a marker of differentiation in the mouse testis and ovary. Endocrinology 136 2960-2970.

Bathgate RAD, Samuel CS, Burazin TCD, Gundlach AL \& Tregear GW 2003 Relaxin: new peptides, receptors and novel actions. Trends in Endocrinology and Metabolism 14 207-213.

Bathgate RAD, Ivell R, Sanborn BM, Sherwood OD \& Summers RJ 2005 Receptors for relaxin family peptides. Annals of the New York Academy of Sciences 1041 61-76.

Blom IE, van Dijk AJ, Wieten L, Duran K, Ito Y, Kleij L, deNichilo M, Rabelink TJ, Weening JJ, Aten J et al. 2001 In vitro evidence for differential involvement of CTGF, TGF $\beta$, and PDGF-BB in mesangial response to injury. Nephrology, Dialysis, Transplantation 16 1139-1148.

Bogatcheva NV \& Agoulnik AI 2005 INSL3/LGR8 role in testicular descent and cryptorchidism. Reproductive Biomedicine Online 10 49-54.

Bogatcheva NV, Truong A, Feng S, Engel W, Adham IM \& Agoulnik AI 2003 GREAT/LGR8 is the only receptor for insulin-like 3 peptide. Molecular Endocrinology 17 2639-2646.

Boockfor FR, Fullbright G, Bullesbach EE \& Schwabe C 2001 Relaxin-like factor (RLF) serum concentrations and gubernaculum RLF receptor display in relation to pre- and neonatal development of rats. Reproduction 122 899-906.

Büllesbach EE \& Schwabe C 2005 LGR8 signal activation by the relaxin-like factor. Journal of Biological Chemistry 280 14586-14590.

Büllesbach EE, Rhodes R, Rembiesa B \& Schwabe C 1999 The relaxin-like factor is a hormone. Endocrine 10 167-169.

Burazin TCD, Bathgate RAD, Macris M, Layfield S, Gundlach AL \& Tregear GW 2002 Restricted, but abundant, expression of the novel rat gene-3 (R3) relaxin in the dorsal tegmental region of brain. Journal of Neurochemistry 82 1553-1557.

Burazin TCD, Johnson KJ, Ma S, Bathgate RAD, Tregear GW \& Gundlach AL 2005 Localization of LGR7 (relaxin receptor) mRNA and protein in rat forebrain: Correlation with relaxin binding site distribution. Annals of the New York Academy of Sciences $1041205-210$.

Danielson LA, Sherwood OD \& Conrad KP 1999 Relaxin is a potent renal vasodilator in conscious rats. Journal of Clinical Investigation $103525-533$.

Feld SM, Hirschberg R, Artishevsky A, Nast C \& Adler SG 1995 Insulin-like growth factor I induces mesangial proliferation and increases mRNA and secretion of collagen. Kidney International 48 45-51.

Ferlin A, Simonato M, Bartoloni L, Rizzo G, Bettella A, Dottorini T, Dallapiccola B \& Foresta C 2003 The INSL3-LGR8/GREAT ligand-receptor pair in human cryptorchidism. Journal of Clinical Endocrinology and Metabolism 88 4273-4279.

Floege J, Eng E, Young BA, Alpers CE, Barrett TB, Bowen-Pope DF \& Johnson RJ 1993 Infusion of platelet-derived growth factor or basic fibroblast growth factor induces selective glomerular mesangial cell proliferation and matrix accumulation in rats. Journal of Clinical Investigation 92 2952-2962. 
Fu P, Layfield S, Ferraro T, Tomiyama H, Hutson J, Otvos LJ, Tregear GW, Bathgate RAD \& Wade JD 2004 Synthesis, conformation, receptor binding and biological activities of monobiotinylated human insulin-like peptide 3. Journal of Peptide Research 63 91-98.

Fu P, Shen P-J, Zhao C-X, Scott DJ, Samuel CS, Wade JD, Tregear GW, Bathgate RAD \& Gundlach AL 2005 Detection, localization and action of the INSL3 receptor - LGR 8 - in rat kidney. Annals of the New York Academy of Sciences 1041 516-519.

Gruden G, Thomas S, Burt D, Lane S, Chusney G, Sacks S \& Viberti G 1997 Mechanical stretch induces vascular permeability factor in human mesangial cells: mechanisms of signal transduction. PNAS 94 12112-12116.

Haas CS, Schocklmann HO, Lang S, Kralewski M \& Sterzel RB 1999 Regulatory mechanism in glomerular mesangial cell proliferation. Journal of Nephrology 12 405-415.

Hansen MB, Nielsen SE \& Berg K 1989 Re-examination and further development of a precise and rapid dye method for measuring cell growth/cell kill. Journal of Immunological Methods 119 203-210.

Harrison-Bernard LM, Navar LG, Ho MM, Vinson GP \& el-Dahr SS 1997 Immunohistochemical localization of ANG II AT1 receptor in adult rat kidney using a monoclonal antibody. American Journal of Physiology 273 F170-F177.

Hoffmann S, Podlich D, Hahnel B, Kriz W \& Gretz N 2004 Angiotensin II type 1 receptor overexpression in podocytes induces glomerulosclerosis in transgenic rats. Journal of the American Society of Nephrology 15 1475-1487.

Hsu SYT 2003 New insights into the evolution of the relaxin-LGR signaling system. Trends in Endocrinology and Metabolism 14 303-309.

Hsu SYT, Nakabayashi K, Nishi S, Kumagai J, Kudo M, Sherwood OD \& Hsueh AJW 2002 Activation of orphan receptors by the hormone relaxin. Science 295 671-674.

Hutson JM, Hasthorpe S \& Heyns CF 1997 Anatomical and functional aspects of testicular descent and cryptorchidism. Endocrine Reviews 18 259-280.

Ivell R 1997 Biology of the relaxin-like factor (RLF). Reviews of Reproduction 2 133-138.

Jaffer F, Saunders C, Shultz P, Throckmorton D, Weinshell E \& Abboud HE 1989 Regulation of mesangial cell growth by polypeptide mitogens. Inhibitory role of transforming growth factor beta. American Journal of Pathology 135 261-269.

Kamat AA, Feng S, Bogatcheva NV, Truong A, Bishop CE \& Agoulnik AI 2004 Genetic targeting of relaxin and insulin-like factor 3 receptors in mice. Endocrinology 145 4712-4720.

Kawamura K, Kumagai J, Sudo S, Chun S-Y, Pisarska M, Morita H, Toppari J, Fu P, Wade JD, Bathgate RAD et al. 2004 Paracrine regulation of oocyte maturation and male germ cell survival. PNAS $1017323-7328$

Kubota Y, Temelcos C, Bathgate RAD, Smith KJ, Scott DJ, Zhao C \& Hutson JM 2002 The role of insulin 3, testosterone, Mullerian inhibiting substance and relaxin in rat gubernacular growth. Molecular Human Reproduction 8 900-905.

Kumagai J, Hsu SY, Matsumi H, Roh JS, Fu P, Wade JD, Bathgate RAD \& Hsueh AJW 2002 INSL3/Leydig insulin-like peptide activates the LGR8 receptor important in testis descent. Journal of Biological Chemistry 277 31283-31286.

Loveland BE, Johns TG, Mackay IR, Vaillant F, Wang ZX \& Hertzog PJ 1992 Validation of the MTT dye assay for enumeration of cells in proliferative and antiproliferative assays. Biochemistry International 27 501-510.

Ma J, Matsusaka T, Yang H, Kawachi H, Shimizu F, Isaka Y, Imai E, Kon V \& Ichikawa I 2004 Local actions of endogenous angiotensin II in injured glomeruli. Journal of the American Society of Nephrology 15 1268-1276.
Nef S \& Parada LF 1999 Cryptorchidism in mice mutant for Insl3. Nature Genetics 22 295-299.

Norwood VF, Craig MR, Harris JM \& Gomez RA 1997 Differential expression of angiotensin II receptors during early renal morphogenesis. American Journal of Physiology 272 R662-R668.

Overbeek PA, Gorlov IP, Sutherland RW, Houston JB, Harrison WR, Boettger-Tong HL, Bishop CE \& Agoulnik A 2001 A transgenic insertion causing cryptorchidism in mice. Genesis 30 26-35.

Pabst R \& Sterzel RB 1983 Cell renewal of glomerular cell types in normal rats. An autoradiographic analysis. Kidney International 24 626-631.

Saile B, DiRocco P, Dudas J, El-Armouche H, Sebb H, Eisenbach C, Neubauer K \& Ramadori G 2004 IGF-I induces DNA synthesis and apoptosis in rat liver hepatic stellate cells (HSC) but DNA synthesis and proliferation in rat liver myofibroblasts (rMF). Laboratory Investigation 84 1037-1049.

Schoecklmann HO, Rupprecht HD, Zauner I \& Sterzel RB 1997 TGF-beta1-induced cell cycle arrest in renal mesangial cells involves inhibition of cyclin E-cdk 2 activation and retinoblastoma protein phosphorylation. Kidney International 51 1228-1236.

Schoecklmann HO, Lang S \& Sterzel RB 1999 Regulation of mesangial cell proliferation. Kidney International 56 1199-1207.

Scott DJ, Layfield S, Riesewijk A, Morita H, Tregear GW \& Bathgate RAD 2004 Identification and characterization of the mouse and rat relaxin receptors as the novel orthologs of human LGR7. Clinical and Experimental Pharmacology and Physiology $31828-832$.

Scott DJ, Fu P, Shen P-J, Gundlach AL, Layfield S, Riesewijk A, Tomiyama H, Hutson JM, Tregear GW \& Bathgate RAD 2005 Characterization of the rat INSL3 receptor. Annals of the New York Academy of Sciences 1041 13-16.

Shankland SJ \& Johnson RJ 1998 TGF- $\beta$ in glomerular disease. Mineral and Electrolyte Metabolism 24 168-173.

Shen P-J \& Gundlach AL 1996 Chromogranin mRNA levels in the brain as a marker for acute and chronic changes in neuronal activity: Effect of treatments including seizures, osmotic stimulation and axotomy in the rat. European Journal of Neuroscience 8 988-1000.

Shen P-J, Fu P, Phelan KD, Scott DJ, Layfield S, Tregear GW, Bathgate RAD \& Gundlach AL 2005 Restricted expression of LGR 8 in intralaminar thalamic nuclei of rat brain suggests a role in sensorimotor systems. Annals of the New York Academy of Sciences $1041510-515$.

Siebel AL, Gehring HM, Nave CD, Bathgate RAD, Borchers CE \& Parry LJ 2002 The upregulation of mesotocin receptors in the tammar wallaby myometrium is pregnancy-specific and independent of estrogen. Biology of Reproduction 66 1237-1243.

Spiess AN, Balvers M, Tena-Sempere M, Huhtaniemi I, Parry L \& Ivell R 1999 Structure and expression of the rat relaxin-like factor (RLF) gene. Molecular Reproduction and Development 54 319-325.

Wisden W \& Morris BJ 2002 In situ hybridization with oligonucleotide probes. International Review of Neurobiology 47 3-59.

Zimmermann S, Steding G, Emmen JM, Brinkmann AO, Nayernia K, Holstein AF, Engel W \& Adham IM 1999 Targeted disruption of the Insl3 gene causes bilateral cryptorchidism. Molecular Endocrinology 13 681-691.

Received in final form 19 January 2006

Accepted 6 February 2006

Made available online as an Accepted Preprint

13 March 2006 